\title{
THE RESEARCH OF TRANSMISSION OF DVB-C TELEVISION SIGNALS BASED ON THE PROTOTYPE OF TRANSCEIVER OPERATING IN THE LOWER PART OF TERAHERTZ BAND
}

\author{
Gleb L. Avdeyenko, Theodor N. Narytnik, Anton V. Yermakov \\ The Institute of Telecommunication Systems \\ National Technical University of Ukraine "Igor Sikorsky Kyiv Politechnic Institute", Kyiv, Ukraine
}

\begin{abstract}
Background. Currently digital microwave radio relay links operating in centimeter bands and in the lower part of millimeter bands $(3.4-40.5 \mathrm{GHz})$ are widely used in the leading countries to construct their telecommunication infrastructure. Taking into account the lack of spectrum in these frequency bands and growing necessity to transmit high-rate applications with the help of brand-new radio relay equipment of the world leading manufacturers of such equipment, tendency to operate in higher parts of millimeter bands is becoming more real and practicable. At the same time, the terahertz band (100-3000 GHz) which is not used at the present time (because of complexity of construction of radio relay equipment that could operate in this band) is also very perspective for introduction of the future radio relay equipment (for the reason of high information capacity of 100$3000 \mathrm{GHz}$ band). The Research Telecommunication Institute of the National Technical University of Ukraine and the Institute of Electronics and Communications of the Ukrainian Academy of Science developed the prototype of the transceiver for operation in the lower part of the terahertz band (130-132 GHz band). For this reason there was a necessity to conduct research concerning operation of the prototype in $130-132 \mathrm{GHz}$ band (that is to test quality of operation of separate blocks of transceiver by changing parameters of transmitting signals passing through it).
\end{abstract}

Objective. The purpose of the research is the parameters variation of multichannel digital broadcasting TV signals based on DVB-C standard when TV signal is transmitted through the $130 \mathrm{GHz}$ transceiver prototype. DVB-C standard has been chosen for this research to have opportunity to analyze signals with different modulation schemes (from QAM-64 to QAM-256), which allowed investigating the influence of certain prototype node parameters on the signal parameters that were transmitted through it

Methods. To conduct the research the experimental installation has been constructed with several parts in it (transceiver, subsystem for generation of DVB-C television signals, subsystem for measurement of DVB-C television signal parameters). The research has been conducted in three stages using a step-by-step approach with application of one-channel, two-channel and three-channel signals of DVB-C standard.

Results. Results of the research showed that the use of the transceiver (that has common heterodyne for transmitting and receiving parts) in the lower part of terahertz band $(130 \mathrm{GHz})$ permits to transmit three TV broadcasting channels of DVB-C standard in $24 \mathrm{MHz}$ bandwidth with transmission rate of $125 \mathrm{Mbit} / \mathrm{s}$ with high subjective quality of all TV programs.

Conclusions. The results of the research demonstrated high quality of digital TV signals transmission by means of transceiver constructed for application in terahertz band (130-132 GHz). The reason for such conclusion is that harmonic distortions have not been observed and phase noise of heterodyne has not led to significant channel symbols distortion on signal constellation. The next step in future research will include the research of the quality of DVB-C signal transmission for cases when terahertz radio link is used and specific heterodynes are applied in transmitting and receiving parts of the transceiver prototype. In the future the transceiver can be used for construction of digital microwave radio relay links in terahertz band for transmission and reception of digital TV signals with high rate both for broadcasting and other applications such as Internet.

Keywords: terahertz band; transceiver; transmitting and receiving parts; TV broadcasting multichannel signal; DVB-C standard.

\section{Introduction}

Currently a large amount of digital radio relay equipment operating in the band $3.4-40.5 \mathrm{GHz}$ has been introduced in Ukraine and other countries. Taking into account the excessive occupancy of this band tendency for new radio relay links to be operated in higher parts of millimeter bands is becoming more practicable (Eband, 71-76 GHz, 81-86 GHz, 92-95 GHz) [1]. The world leading manufacturers have already presented a wide variety of radio relay equipment operating in Eband. Besides, the scientific society of certain countries considers the possibility to use some parts of spectrum from $100 \mathrm{GHz}$ to $3000 \mathrm{GHz}$ (terahertz band) for introduction of the future radio relay links [2].

First of all, the terahertz band is very perspective for introduction of future radio relay links because it provides high information capacity (its capacity is 100 
times more than centimeter bands one). Secondly, the terahertz band is convenient for the reason that no interferences are expected from other radio electronic equipment, so it will allow the simplest methods of modulation and antinoise coding to be implemented in it.

The radiation in terahertz band can have wide practical applications, for example, for transmission of TV signals of high quality. But on the other hand, terahertz waves are located in spectrum area between the microwave radiation and the middle infrared area, and it is very difficult to work with terahertz band for two reasons. First of all, necessary electronic components for construction of radio equipment in terahertz band are absent now, and secondly, significant absorption of electromagnetic waves energy by different hydrometeors takes place (it means that extension of intervals of radio relay links is limited to distances from hundreds of meters to several kilometers).

Concerning creation of electronic components for terahertz band it is important to note that scientists and engineers worldwide are working on this problem and collaborating. Using recent achievements in nanotechnology area, a team of scientists from Chalmers University of Technology and University College London developed and produced the prototype of the highfrequency amplifier of radio signals that has the widest bandwidth at the present time. Its bandwidth starts at several gigahertz level and ends at value of $235 \mathrm{GHz}$ [3]. In this bandwidth amplifier provides amplification of radio signal for more than $15 \mathrm{~dB}$. Upper limit of operating frequency is located in the area of $1.5 \mathrm{THz}$ that exceeds operating frequencies for all similar equipment developed earlier.

Research Institute of Telecommunications of National Technical University of Ukraine "Igor Sikorsky Kyiv Polytechnic Institute" in cooperation with the Institute of Electronics and Communications of the Ukrainian Academy of Science takes an active part in research of terahertz band, in creation of electronic components and also takes part in development of telecommunication equipment based on above-mentioned components (such as transmitting and receiving parts of radio relay equipment operating in $130-132 \mathrm{GHz}$ band [2-10]).

The purpose of the above-mentioned activity is to research modification of TV broadcasting multichannel signal based on DVB-C standard when this signal is transmitted between separate blocks inside the prototype of $130 \mathrm{GHz}$ band transceiver. DVB-C standard has been chosen for this research to have opportunity to analyze signals with different position modulations (from QAM-64 to QAM-256). It allowed influence of parameters of prototype blocks on signal parameters that have been transmitted inside of prototype to be analyzed with precise conclusions.

\section{Main part}

To research changes of TV broadcasting multichannel signals based on DVB-C standard upon their transmission inside of the prototype (in terahertz band) the experimental installation has been constructed. The diagram of this installation is shown in Fig.1.

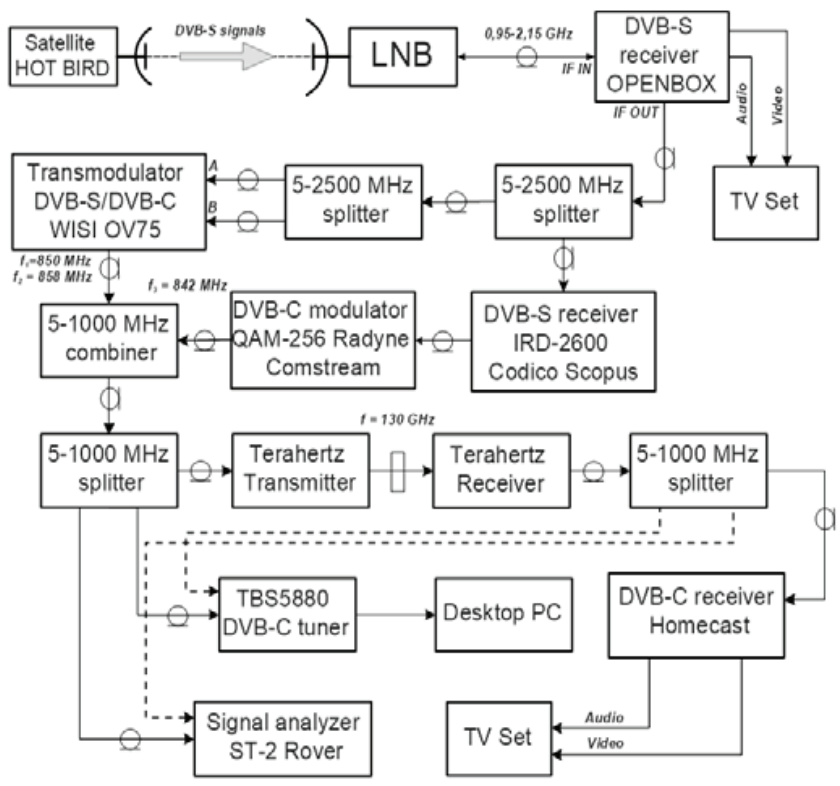

Fig.1. Diagram of experimental installation constructed for the research of DVB-C TV broadcasting multichannel signals

As it can be seen in Fig.1, measurements of parameters of DVB-C signals have been implemented at the input of transmitting part and at the output of receiving part of the prototype. To perform measurements transmitter output was connected to the receiver input by means of waveguide line.

Simplified block diagram of transceiver operating in terahertz band and its photo are represented in Fig.2 and Fig.3. The measurement equipment that was used at all stages of the research was the following:

- ST-2 ROVER analyzer of TV signals;

- Receiver of digital cable television of DVB-C standard (Homecast) connected to TV set (Samsung). The receiver has been used for determination of quality of DVB-C signal in the relative scale of percentage at the transmitter input and at the receiver output for terahertz band;

- Tuner of digital television QBox TBS5880 that was connected to computer by means of the USB-cable. The tuner is designated for reception of constellation diagrams and numeric indexes of demodulation/decoding quality of DVB-C TV signals (such as 
signal-to-noise ratio (SNR)) at the transmitter input and at the receiver output in terahertz band.

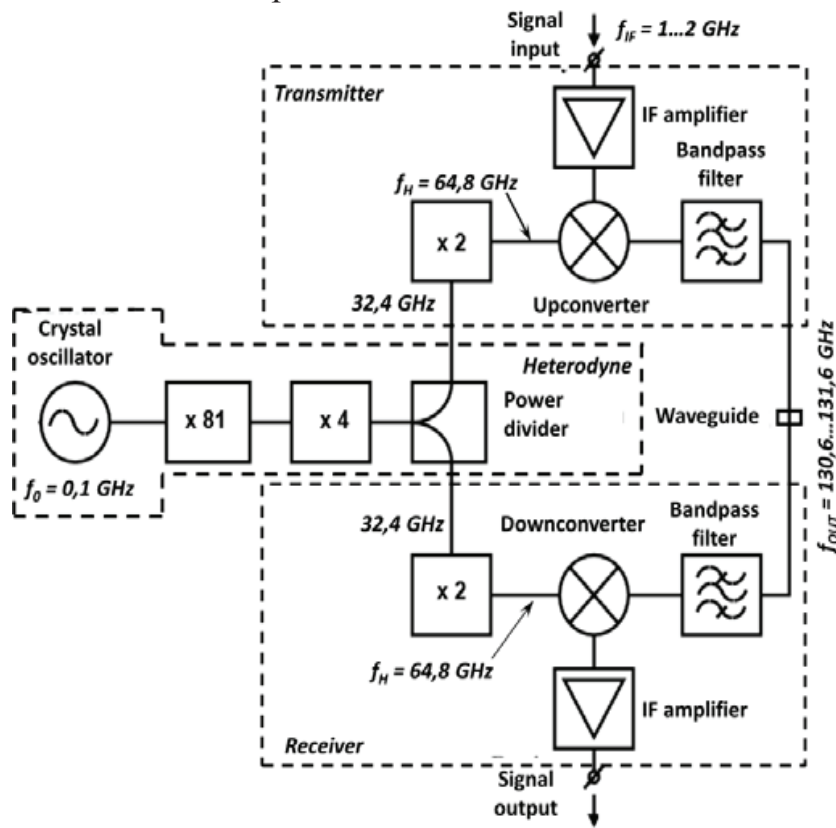

Fig.2. Simplified block diagram of the transceiver designed for operation in terahertz band

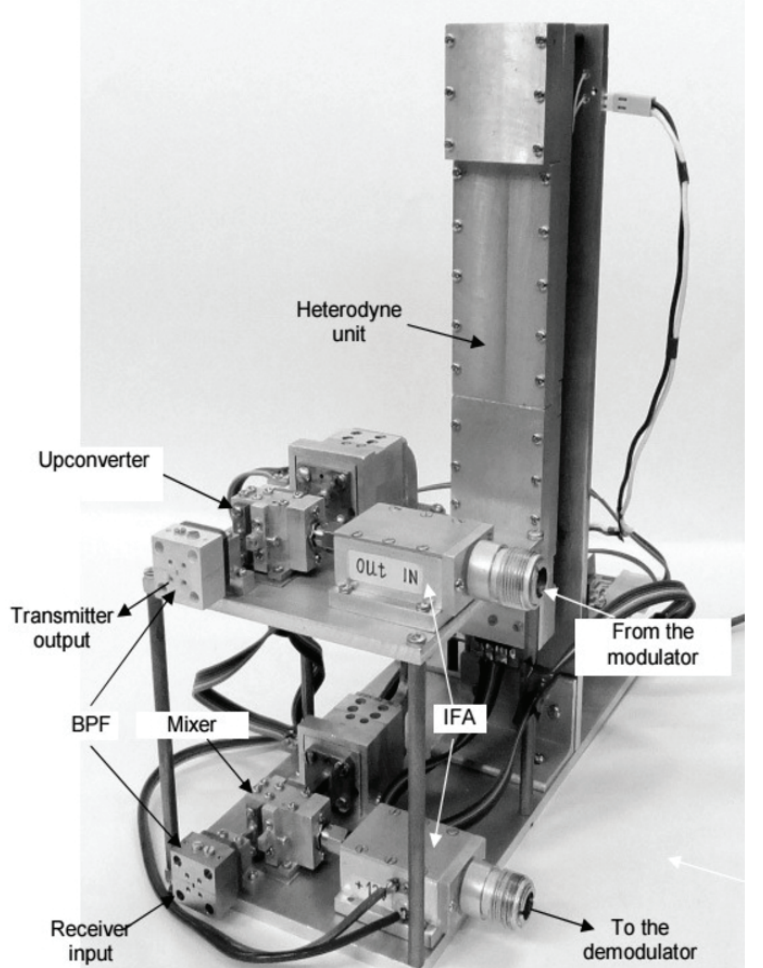

Fig.3. Photo of the transceiver designed for operation in terahertz band

The use of ST-2 ROVER signal analyzer permits to measure the following parameters of DVB-C signals at the transmitter input and at the receiver output (in terahertz band):
- Signal level (LEV), dBm;

- Carrier-to-noise ratio $(\mathrm{C} / \mathrm{N}), \mathrm{dB}$;

- Noise margin (N. MAR), dB;

- TV signal spectrum flatness (FLAT), dB;

- Coefficient of bit error rate (BER).

It is important to note that ST-2 ROVER signal analyzer was operated in the emulation mode during the research process. For this reason values of signal power obtained with the help of ST-2 ROVER signal analyzer are $15 \mathrm{~dB}$ less then ones obtained with the help of TBS5880 tuner.

The research of multichannel signal parameters (Fig.4) of DVB-C digital television (both in transmitting and receiving parts) of the terahertz band has been conducted on step-by-step basis. It means that 1channel, 2-channel and 3-channel signals of DVB-C standard have been applied consequently. Input signal parameters are represented in Table 1. Generation of DVB-C signals has been implemented with the help of WISI OV75 transmodulator based on DVB-S TV broadcasting signals (parameters of DVB-S signals are also represented in Table 1). DVB-S TV broadcasting signals specified in Table 1 has been received by reflector antenna with convertor (HOT BIRD downlink satellite signals in orbital position 13E have been used).

Using operating functions of WISI OV75 transmodulator it was possible to modify such parameters of DVB-C signal as modulation (QAM-16, QAM-32, QAM-64, QAM-128, QAM-256), rate (symbol or bit rate depending on modulation and interference immunity coding), intermediate frequency (in frequency band $47-862 \mathrm{MHz})$.

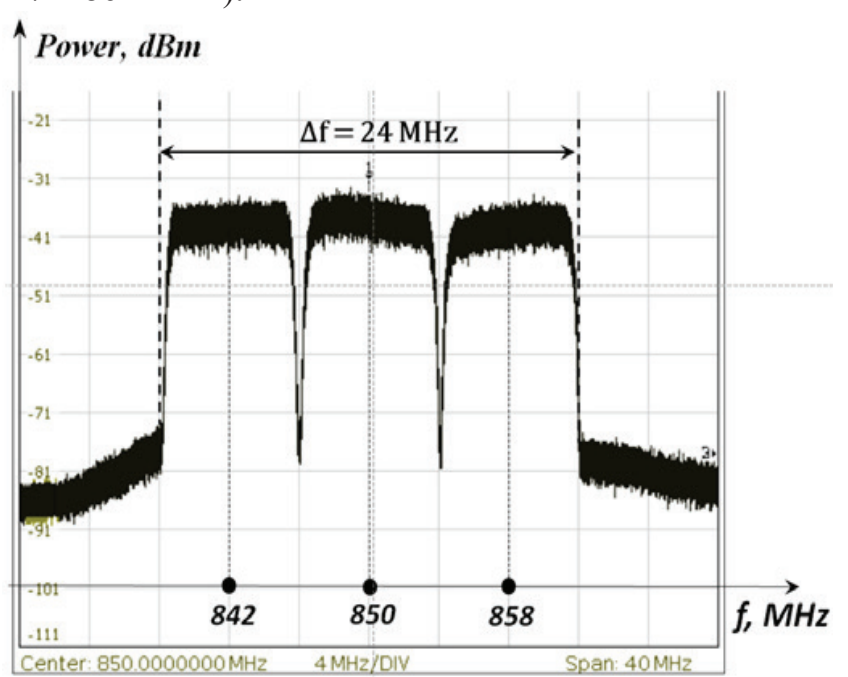

Fig.4 Diagram of three-channel DVB-C signal

Each of three DVB-C TV signals represented in Fig.2 contains MPEG traffic flow with ability to transmit 5-6 TV programs of standard definition quality in open access. 
Table 1. Input parameters of digital TV broadcasting signals (HOT BIRD satellite downlink signals operated in orbital position 13E have been used)

\begin{tabular}{|c|c|c|c|c|c|c|c|c|c|}
\hline \multirow{2}{*}{$\begin{array}{l}\text { Channel } \\
\text { number }\end{array}$} & \multirow{2}{*}{$\begin{array}{c}\text { Input signal, } \\
\mathrm{MHz}\end{array}$} & \multirow{2}{*}{$\begin{array}{c}\text { Intermediate } \\
\text { frequency, } \\
\mathrm{MHz}\end{array}$} & \multirow{2}{*}{$\begin{array}{c}\text { Symbol rate, } \\
\mathrm{Ksym} / \mathrm{sec}\end{array}$} & \multirow{2}{*}{$\begin{array}{l}\text { Bit rate, } \\
\text { MBit/sec }\end{array}$} & \multirow{2}{*}{ Modulation } & \multicolumn{2}{|c|}{ FEC } & \multirow{2}{*}{$\begin{array}{l}\text { Information } \\
\text { rate, MBit/s }\end{array}$} & \multirow{2}{*}{$\begin{array}{c}\text { Bandwidth, } \\
\text { MHz }\end{array}$} \\
\hline & & & & & & Conv. & $\begin{array}{c}\text { Reed- } \\
\text { Solomon }\end{array}$ & & \\
\hline 1 & 11179 & 1429 & 27500 & 55 & QPSK & $3 / 4$ & $188 / 204$ & 38,015 & 36 \\
\hline 2 & 11137 & 1387 & 27500 & 55 & QPSK & $3 / 4$ & $188 / 204$ & 38,015 & 36 \\
\hline 3 & 11334 & 1584 & 27500 & 55 & QPSK & $3 / 4$ & $188 / 204$ & 38,015 & 36 \\
\hline
\end{tabular}

Results of the first stage of the research of DVB-C signal (carrier frequency $\mathrm{F}=850 \mathrm{MHz}$ ) when transmitting in terahertz band are represented in Tables 2-3 and

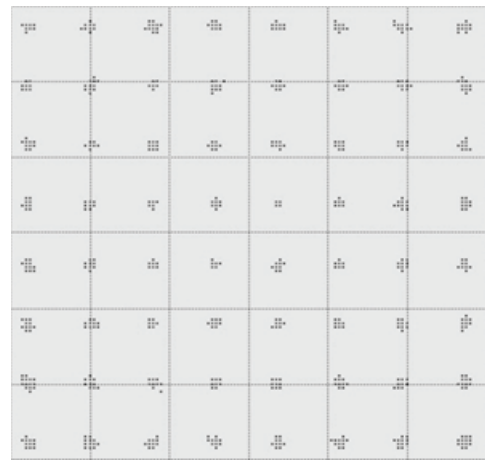

Fig.5 Constellation diagram of DVB-C signal when QAM-64 modulation is applied in figures 5-6.

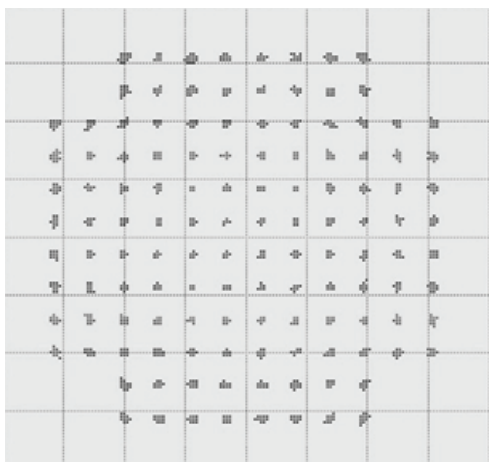

Fig.6 Constellation diagram of DVB-C signal when QAM-128 modulation is applied

Table 2. Parameters of TV broadcasting one-channel signal of DVB-C standard (carrier frequency $f=850 \mathrm{MHz}$ ) that have been measured with the use of ROVER ST-2 signal analyzer and Homecast receiver

\begin{tabular}{|c|c|c|c|c|c|c|c|c|}
\hline $\begin{array}{c}\text { Measure- } \\
\text { ment port }\end{array}$ & $\begin{array}{c}\mathbf{L E V}, \mathbf{d B m} \\
\mathbf{d B}\end{array}$ & $\begin{array}{c}\mathbf{C} / \mathbf{N B}, \\
\mathbf{d B}\end{array}$ & $\begin{array}{c}\text { N. MAR, } \\
\mathbf{d B}\end{array}$ & $\begin{array}{c}\text { FLAT, } \\
\mathbf{d B}\end{array}$ & $\mathbf{B E R}$ & Modulation & $\begin{array}{c}\text { Symbol rate, } \\
\text { Msymb/sec }\end{array}$ & $\begin{array}{c}\text { Quality, } \\
\mathbf{\%}\end{array}$ \\
\hline $\begin{array}{c}\text { Receiver } \\
\text { output }\end{array}$ & $-23,3$ & $>36$ & 16 & $2-3$ & $<10^{-8}$ & QAM-64 & 6,875 & 100 \\
\hline $\begin{array}{c}\text { Transmitter } \\
\text { input }\end{array}$ & $-24,8$ & $>36$ & $13-14$ & $3-4$ & $<10^{-8}$ & QAM-128 & 5,895 & $92-100$ \\
\hline $\begin{array}{c}\text { Receiver } \\
\text { output }\end{array}$ & $-36,5$ & $>36$ & 12 & 2 & $<10^{-8}$ & QAM-128 & 5,895 & $92-100$ \\
\hline $\begin{array}{c}\text { Transmitter } \\
\text { input }\end{array}$ & $-17,3$ & $>36$ & 20 & $2-3$ & $<10^{-8}$ & QAM-256 & 5,156 & $33-60$ \\
\hline $\begin{array}{c}\text { Receiver } \\
\text { output }\end{array}$ & $-28,6$ & $33-34$ & 9 & $2-4$ & $<10^{-8}$ & QAM-256 & 5,156 & $33-60$ \\
\hline
\end{tabular}

Table 3. Parameters of TV broadcasting one-channel signal of DVB-C standard (carrier frequency $f=850 \mathrm{MHz}$ ) that have been measured with the use of TBS 8550 tuner

\begin{tabular}{|c|c|c|c|c|c|c|c|}
\hline \multicolumn{2}{|c|}{$\begin{array}{c}\text { Results of measurements at the } \\
\text { transmitter input (in terahertz } \\
\text { band) }\end{array}$} & \multicolumn{2}{c|}{$\begin{array}{c}\text { Results of measurements at the receiver out- } \\
\text { put (in terahertz band) }\end{array}$} \\
\hline $\begin{array}{c}\text { Frequency, } \\
\text { MHz }\end{array}$ & Modulation & $\begin{array}{c}\text { LEV, } \\
\text { dBm }\end{array}$ & SNR, dB & BER & $\begin{array}{c}\text { LEV, } \\
\text { dBm }\end{array}$ & SNR, dB & BER \\
\hline \multirow{3}{*}{850} & QAM-64 & -35 & 38,6 & $<10^{-8}$ & -51 & 36,2 & $<10^{-8}$ \\
\cline { 2 - 8 } & QAM-128 & -35 & 42,78 & $<10^{-8}$ & -51 & 42,12 & $<10^{-8}$ \\
\cline { 2 - 8 } & QAM-256 & -29 & 38,6 & $5 \cdot 10^{-8}$ & -51 & 37,4 & $9 \cdot 10^{-8}$ \\
\hline
\end{tabular}

Results of the research represented in Tables 2 and 3 show that interference immunity margin equals to $9 \mathrm{~dB}$ even when QAM-256 modulation is applied (that is acceptable to provide reliable broadcasting of TV programs with accepted quality of 33-60\%).
When the second stage of the research was conducted the second receiving channel of transmodulator WISI OV75 (B input) have been activated in experimental installation (DVB-S TV signal received from 
HOT BIRD satellite has been applied at the B input Table 1).

When converting DVB-S signals into DVB-C ones with the help of transmodulator, carrier frequencies $f_{1}=850 \mathrm{MHz}$ and $f_{2}=858 \mathrm{MHz}$ have been chosen for
DVB-C signals (Fig.2). This DVB-C signals have been applied in terahertz band at the input of the transceiver transmitting part. After that necessary measurements have been carried out at the output of the transceiver receiving part (Tables $4,5,6$ ).

Table 4. Parameters of TV broadcasting two-channel signal of DVB-C standard (channel №1, intermediate frequency

$\mathrm{F}_{1}=850 \mathrm{MHz}$ ) that have been measured with the use of ROVER ST-2 signal analyzer and Homecast receiver

\begin{tabular}{|c|c|c|c|c|c|c|c|c|}
\hline $\begin{array}{c}\text { Measurement } \\
\text { port }\end{array}$ & $\begin{array}{c}\text { LEV, } \\
\mathbf{d B m}\end{array}$ & $\mathbf{C / N} \mathbf{d B}$ & $\begin{array}{c}\text { N. MAR } \\
\mathbf{d B}\end{array}$ & $\begin{array}{c}\text { FLAT, } \\
\mathbf{d B}\end{array}$ & $\mathbf{B E R}$ & Modulation & $\begin{array}{c}\text { Symbol } \\
\text { rate, } \\
\text { Msymb/s }\end{array}$ & $\begin{array}{c}\text { Quality, } \\
\%\end{array}$ \\
\hline $\begin{array}{c}\text { Transmitter } \\
\text { input }\end{array}$ & -26 & 34 & 9 & 5 & $<10^{-8}$ & QAM-64 & 6,875 & 100 \\
\hline $\begin{array}{c}\text { Receiver } \\
\text { output }\end{array}$ & -39 & 31 & 6 & 6 & $<10^{-8}$ & QAM-64 & 6,875 & 100 \\
\hline $\begin{array}{c}\text { Transmitter } \\
\text { input }\end{array}$ & -23.8 & $>36$ & 11 & 3 & $<10^{-8}$ & QAM-128 & 5,892 & $60-100$ \\
\hline $\begin{array}{c}\text { Receiver } \\
\text { output }\end{array}$ & -36.7 & 34 & 8 & 5 & $<10^{-8}$ & QAM-128 & 5,892 & $60-100$ \\
\hline $\begin{array}{c}\text { Transmitter } \\
\text { input }\end{array}$ & -18 & 34 & 6 & 2 & $10^{-6}$ & QAM-256 & 5,156 & $18-23$ \\
\hline $\begin{array}{c}\text { Receiver } \\
\text { output }\end{array}$ & -27 & 29 & 5 & 3 & $10^{-6}$ & QAM-256 & 5,156 & $18-23$ \\
\hline
\end{tabular}

Table 5. Parameters of TV broadcasting two-channel signal of DVB-C standard (channel №2, intermediate frequency $\mathrm{F}_{1}=858 \mathrm{MHz}$ ) that have been measured with the use of ROVER ST-2 signal analyzer and Homecast receiver

\begin{tabular}{|c|c|c|c|c|c|c|c|c|}
\hline $\begin{array}{c}\text { Measurement } \\
\text { port }\end{array}$ & $\begin{array}{c}\mathbf{L E V}, \\
\mathbf{d B m}\end{array}$ & $\mathbf{C} / \mathbf{N}, \mathbf{d B}$ & $\begin{array}{c}\mathbf{N} . \text { MAR } \\
\mathbf{d B}\end{array}$ & $\begin{array}{c}\text { FLAT, } \\
\mathbf{d B}\end{array}$ & $\mathbf{B E R}$ & Modulation & $\begin{array}{c}\text { Symbol } \\
\text { rate, } \\
\text { Msymb/s }\end{array}$ & $\begin{array}{c}\text { Quality, } \\
\%\end{array}$ \\
\hline $\begin{array}{c}\text { Transmitter } \\
\text { input }\end{array}$ & -28 & $>36$ & 14 & 3 & $<10^{-8}$ & QAM-64 & 6,875 & 100 \\
\hline $\begin{array}{c}\text { Receiver } \\
\text { output }\end{array}$ & -36 & 33 & 8 & 4 & $<10^{-8}$ & QAM-64 & 6,875 & 100 \\
\hline $\begin{array}{c}\text { Transmitter } \\
\text { input }\end{array}$ & -29 & $>36$ & 11 & 4 & $<10^{-8}$ & QAM-128 & 5,892 & $60-100$ \\
\hline $\begin{array}{c}\text { Receiver } \\
\text { output }\end{array}$ & -36.6 & 32 & 8 & 4 & $<10^{-8}$ & QAM-128 & 5,892 & $60-100$ \\
\hline $\begin{array}{c}\text { Transmitter } \\
\text { input }\end{array}$ & -17.4 & 34 & 16 & 3 & $10^{-5}$ & QAM-256 & 5,156 & $18-23$ \\
\hline $\begin{array}{c}\text { Receiver } \\
\text { output }\end{array}$ & -27 & 30 & 7 & 4 & $10^{-5}$ & QAM-256 & 5,156 & $18-23$ \\
\hline
\end{tabular}

Table 6. Parameters of TV broadcasting two-channel signal of DVB-C standard that have been measured with the use of TBS8550 tuner

\begin{tabular}{|c|c|c|c|c|c|c|c|}
\hline \multicolumn{2}{|c|}{$\begin{array}{c}\text { Channel parameters } \\
\text { brequency, } \\
\text { MHz }\end{array}$} & \multicolumn{2}{|c|}{$\begin{array}{c}\text { Results of measurements at the } \\
\text { transmitter input (in terahertz } \\
\text { band) }\end{array}$} & \multicolumn{2}{c|}{$\begin{array}{c}\text { Results of measurements at the receiver } \\
\text { output (in terahertz band) }\end{array}$} \\
\hline \multirow{3}{*}{850} & Modulation & LEV, dBm & SNR, dB & BER & LEV, dBm & SNR, dB & BER \\
\cline { 2 - 9 } & QAM-128 & -38 & 38,6 & $<10^{-8}$ & -54 & 37,4 & $<10^{-8}$ \\
\cline { 2 - 9 } & QAM-256 & -38 & 42,12 & $<10^{-8}$ & -54 & 41,07 & $<10^{-8}$ \\
\hline \multirow{3}{*}{858} & QAM-64 & -26 & 38 & $<10^{-8}$ & -38 & 35 & $9 \cdot 10^{-5}$ \\
\cline { 2 - 8 } & QAM-128 & -35 & 38,6 & $<10^{-8}$ & -54 & 36,2 & $<10^{-8}$ \\
\cline { 2 - 8 } & QAM-256 & -26 & 38,6 & $<10^{-8}$ & -54 & 39,43 & $<10^{-8}$ \\
\hline
\end{tabular}


Results of the research obtained during the second research stage show that parameters of each signal became worse in comparison with the previous research for one-channel signal. In our case when QAM-256 modulation is applied BER parameter has been deteriorated to $10^{-6}$, margin of interference immunity has been decreased to $7 \mathrm{~dB}$, signal quality have been reduced by $10-20 \%$. When TBS5880 receiver is used BER parameter has been deteriorated to $10^{-4}$ that corresponds to signal quality equal to 18 $23 \%$. But even under such circumstances HomeCast receiver demodulates DVB-C TV signals and provides high image quality.

When conducting the third research stage the third channel of TV broadcasting multichannel signal has been introduced in the research process (Table 1). The $3^{\text {rd }} \mathrm{TV}$ channel has been obtained with the help of DVB-S OPENBOX receiver (by means of signal on intermediate frequency that IRD-2600
CODICO SCOPUS receiver demodulates to traffic flow). After that the traffic flow via ASI interface enters the QAM modulator (RADYNE COMSTREAM QAM-256) where the necessary modulation (QPSK, QAM-16, QAM-32, QAM-64, QAM-128, QAM-256), traffic flow rate (symbol or bit depending on modulation and interference immunity coding), signal carrier frequency $\left(f_{3}=842\right.$ $\mathrm{MHz}$ ) and traffic flow frame format (188 byte) are chosen.

When the traffic flow have passed through output of QAM modulator (RADYNE COMSTREAM QAM-256) and output of transmodulator (WISI OV75, see Fig.1) it arrives at combiner (at the output of which TV signal reaches transceiver operating in terahertz band). Results of the measurement of parameters of DVB-C three-channel TV signal are represented in Tables 7,8,9,10.

Table 7. Parameters of TV broadcasting three-channel signal of DVB-C standard (channel №1, intermediate frequency $\mathrm{F}_{1}=842 \mathrm{MHz}$ ) that have been measured with the use of ROVER ST-2 signal analyzer and Homecast receiver

\begin{tabular}{|c|c|c|c|c|c|c|c|c|}
\hline $\begin{array}{c}\text { Measurement } \\
\text { port }\end{array}$ & $\begin{array}{c}\text { LEV, } \\
\mathbf{d B m}\end{array}$ & $\mathbf{C} / \mathbf{N}, \mathbf{d B}$ & $\begin{array}{c}\text { N. MAR } \\
\mathbf{d B}\end{array}$ & $\begin{array}{c}\text { FLAT, } \\
\mathbf{d B}\end{array}$ & BER & Modulation & $\begin{array}{c}\text { Symbol } \\
\text { rate, } \\
\text { Msymb/s }\end{array}$ & $\begin{array}{c}\text { Quality, } \\
\%\end{array}$ \\
\hline $\begin{array}{c}\text { Transmitter } \\
\text { input }\end{array}$ & -33 & 36 & 15 & 2 & $<10^{-8}$ & QAM-64 & 6,875 & 100 \\
\hline $\begin{array}{c}\text { Receiver } \\
\text { output }\end{array}$ & -44 & 30 & 5 & 3 & $<10^{-8}$ & QAM-64 & 6,875 & 100 \\
\hline $\begin{array}{c}\text { Transmitter } \\
\text { input }\end{array}$ & -32 & 36 & 17 & 2 & $5 \cdot 10^{-6}$ & QAM-128 & 5,892 & $67-92$ \\
\hline $\begin{array}{c}\text { Receiver } \\
\text { output }\end{array}$ & -43 & 31 & 7 & 2 & $10^{-6}$ & QAM-128 & 5,892 & $67-92$ \\
\hline $\begin{array}{c}\text { Transmitter } \\
\text { input }\end{array}$ & -23 & $>36$ & 11 & 2 & $<10^{-8}$ & QAM-256 & 5,156 & $33-60$ \\
\hline $\begin{array}{c}\text { Receiver } \\
\text { output }\end{array}$ & -32 & 29 & 0 & 3 & $10^{-6}$ & QAM-256 & 5,156 & $33-60$ \\
\hline
\end{tabular}

Table 8.Parameters of TV broadcasting three-channel signal of DVB-C standard (channel №2, intermediate frequency $\mathrm{F}_{2}=850 \mathrm{MHz}$ ) that have been measured with the use of ROVER ST-2 signal analyzer and Homecast receiver

\begin{tabular}{|c|c|c|c|c|c|c|c|c|}
\hline $\begin{array}{c}\text { Measurement } \\
\text { port }\end{array}$ & $\begin{array}{c}\text { LEV, } \\
\mathbf{d B m}\end{array}$ & $\mathbf{C / N}, \mathbf{d B}$ & $\begin{array}{c}\text { N. MAR } \\
\mathbf{d B}\end{array}$ & $\begin{array}{c}\text { FLAT, } \\
\mathbf{d B}\end{array}$ & $\mathbf{B E R}$ & Modulation & $\begin{array}{c}\text { Symbol } \\
\text { rate, } \\
\text { Msymb/s }\end{array}$ & $\begin{array}{c}\text { Quality, } \\
\mathbf{\%}\end{array}$ \\
\hline $\begin{array}{c}\text { Transmitter } \\
\text { input }\end{array}$ & -29 & 36 & 10 & 3 & $<10^{-8}$ & QAM-64 & 6,875 & 100 \\
\hline $\begin{array}{c}\text { Receiver } \\
\text { output }\end{array}$ & -40 & 33 & 8 & 1 & $<10^{-8}$ & QAM-64 & 6,875 & 100 \\
\hline $\begin{array}{c}\text { Transmitter } \\
\text { input }\end{array}$ & -30 & 30 & 9 & 2 & $10^{-7}$ & QAM-128 & 5,892 & $67-100$ \\
\hline $\begin{array}{c}\text { Receiver } \\
\text { output }\end{array}$ & -40 & 23 & 4 & 2 & $10^{-7}$ & QAM-128 & 5,892 & $67-100$ \\
\hline $\begin{array}{c}\text { Transmitter } \\
\text { input }\end{array}$ & -23 & $>36$ & 10 & 3 & $<10^{-8}$ & QAM-256 & 5,156 & $33-58$ \\
\hline $\begin{array}{c}\text { Receiver } \\
\text { output }\end{array}$ & -32 & 28 & 0 & 3 & $10^{-4}$ & QAM-256 & 5,156 & $33-58$ \\
\hline
\end{tabular}

Table 9. Parameters of TV broadcasting three-channel signal of DVB-C standard (channel №1, intermediate frequency $\mathrm{F}_{3}=858 \mathrm{MHz}$ ) that have been measured with the use of ROVER ST-2 signal analyzer and Homecast receiver 


\begin{tabular}{|c|c|c|c|c|c|c|c|c|}
\hline $\begin{array}{c}\text { Measurement } \\
\text { port }\end{array}$ & $\begin{array}{c}\text { LEV, } \\
\mathbf{d B m}\end{array}$ & $\mathbf{C / N}, \mathbf{d B}$ & $\begin{array}{c}\text { N. MAR } \\
\mathbf{d B}\end{array}$ & $\begin{array}{c}\text { FLAT, } \\
\mathbf{d B}\end{array}$ & BER & Modulation & $\begin{array}{c}\text { Symbol } \\
\text { rate, } \\
\text { Msymb/s }\end{array}$ & $\begin{array}{c}\text { Quality, } \\
\%\end{array}$ \\
\hline $\begin{array}{c}\text { Transmitter } \\
\text { input }\end{array}$ & -30 & 33 & 9 & 4 & $<10^{-8}$ & QAM-64 & 6,875 & 100 \\
\hline $\begin{array}{c}\text { Receiver } \\
\text { output }\end{array}$ & -40 & 31 & 7 & 5 & $<10^{-8}$ & QAM- 64 & 6,875 & 100 \\
\hline $\begin{array}{c}\text { Transmitter } \\
\text { input }\end{array}$ & -32 & 34 & 9 & 3 & $<10^{-8}$ & QAM-128 & 5,892 & $67-98$ \\
\hline $\begin{array}{c}\text { Receiver } \\
\text { output }\end{array}$ & -40 & 29 & 5 & 4 & $<10^{-8}$ & QAM-128 & 5,892 & $67-98$ \\
\hline $\begin{array}{c}\text { Transmitter } \\
\text { input }\end{array}$ & -24 & $>36$ & 9 & 3 & $<10^{-8}$ & QAM-256 & 5,156 & $33-53$ \\
\hline $\begin{array}{c}\text { Receiver } \\
\text { output }\end{array}$ & -32 & 29 & $0-1$ & 3 & $10^{-6}$ & QAM-256 & 5,156 & $33-53$ \\
\hline
\end{tabular}

Table 10. Parameters of TV broadcasting three-channel signal of DVB-C standard that have been measured with the use of TBS8550 tuner

\begin{tabular}{|c|c|c|c|c|c|c|c|}
\hline \multicolumn{2}{|c|}{ Channel parameters } & \multicolumn{3}{|c|}{$\begin{array}{l}\text { Results of measurements at the } \\
\text { transmitter input (in terahertz } \\
\text { band) }\end{array}$} & \multicolumn{3}{|c|}{$\begin{array}{l}\text { Results of measurements at the receiver } \\
\text { output (in terahertz band) }\end{array}$} \\
\hline $\begin{array}{c}\text { Frequency, } \\
\mathrm{MHz}\end{array}$ & $\begin{array}{l}\text { Modula- } \\
\text { tion }\end{array}$ & $\begin{array}{l}\text { LEV, } \\
\text { dBm }\end{array}$ & SNR, dB & BER & LEV, dBm & SNR, dB & BER \\
\hline \multirow{3}{*}{842} & QAM-64 & -51 & 38,6 & $<10^{-8}$ & -60 & 33,71 & $<10^{-8}$ \\
\hline & QAM-128 & -54 & 42,12 & $<10^{-8}$ & -57 & 39,43 & $<10^{-8}$ \\
\hline & QAM-256 & -32 & 38,6 & $<10^{-8}$ & -54 & 36,8 & $<10^{-8}$ \\
\hline \multirow{3}{*}{850} & QAM-64 & -38 & 38,6 & $10^{-4}$ & -57 & 37,6 & $7 \cdot 10^{-4}$ \\
\hline & QAM-128 & -54 & 43,43 & $<10^{-8}$ & -54 & 39 & $<10^{-8}$ \\
\hline & QAM-256 & -32 & 38,6 & $<10^{-8}$ & -54 & 37,4 & $<10^{-8}$ \\
\hline \multirow{3}{*}{858} & QAM-64 & -38 & 38 & $<10^{-8}$ & -57 & 34,57 & $<10^{-8}$ \\
\hline & QAM-128 & -54 & 42,12 & $<10^{-8}$ & -54 & 39,43 & $<10^{-8}$ \\
\hline & QAM-256 & -32 & 38,6 & $10^{-3}$ & -54 & 36,8 & $1,5 \cdot 10^{-3}$ \\
\hline
\end{tabular}

Results of the research obtained during the third research stage show that parameters of each signal became worse by 5-6 dB (in comparison with the previous research for DVB-C two-channel signal). Taking into account the worst case scenario BER parameter has been decreased when QAM-256 modulation is applied and TBS5880 tuner was used to measure parameters. The signal quality is equal to $33-53 \%$ in this case.

\section{Conclusion}

Results of the research of TV broadcasting signals parameters of DVB-C standard that have been received with the help of the transceiver prototype operating in terahertz band showed that the use of the lower part of the terahertz band (130 MHz) permits to transmit three TV broadcasting channels of DVB-C standard with $125 \mathrm{Mbit} / \mathrm{s}$ total traffic flow rate in $24 \mathrm{MHz}$ bandwidth having high subjective image quality.

At the present time transmitting and receiving parts of radio equipment operating in terahertz band are supposed to be very demanded in future to provide broadcasting of High-Definition Serial Digital
Interface (HD-SDI) TV programs (transmission rate is presumed to reach values around $1.5 \mathrm{Gbit} / \mathrm{s}$ ). For example, the use of terahertz band transceiver with capacity of 5 Gbit/s will allow high quality multiplex three-channel D-SDI signal without compression (or more than 130 TV channels of DVB-C standard) to be transmitted.

It is also important to note that transceiver operating in terahertz band is presumed to be used for construction of high-rate networks for application not only in telecommunication area but also in other applications. For example, this equipment can be used to interconnect scientific measurement equipment and other devices producing significant information volumes for scientific application.

\section{References}

[1] Vishnevsky V., Shahnovich I., Frolov S. Millimeter band radio relay links: A new horizons // Electronika NTB - 2011. - №1. -P.90-97 [In Russian]

[2] Kravchuk S.O., Narytnik T.M. Terahertz band telecommunication systems. Monograph. - Zhytomir: «Evenok» publishing house, 2014. - 394 p. [in Ukrainian] [3] Widest band amplifier ever at $235 \mathrm{GHz}$ - open door to ultrafast broadband [Electronic resource]. Available at: 
www.chalmers.se/en/news/Pages/widest-band-amplifierever-at-235-GHz.aspx

[4] Ilchenko M. Yu., Narytnik T. M., Radzikhovsky V. M., Kuzmin S. E., Lutchak O. V. Transmitter and receiver parts of radio relay systems operating in the terahertz band // Digital technologies. - 2015., № 17. - P.17-29 [in Ukrainian].

[5] Ilchenko M. Yu., Narytnik T. M., Radzikhovsky V. M. Design of the transmitter and receiver parts of the terahertz band for radio relay systems//Electosvyaz. 2016., №2. - P.42-49 [In Russian].

[6] Ilchenko M.Ye. Transceiver for 130-134 GHZ band and digital radio relay system/M.Ye. Ilchenko, T.N. Narytnik, S.Ye. Kuzmin // Telecommunications and Radio Engineering. - 2013. - vol. 72, №17. - P.1623-1638.

[7] Ilchenko M. Ye., Narytnik T.M., Radzikhovsky V. M. Terahertz band radio relay system functional elements simulation //Problems of telecommunications. - 2013. №2(11). - P.95-113 [in Russian]

[8] Ilchenko M. Ye., Kuzmin S.E., Narytnik T. N. Transceiver for digital radio relay system in terahertz frequency band//Proceedings of 23th International Conference "Microwave Engineering and Telecommunication Technology", Sevastopol, Ukraine, September 8-13, 2013. - Sevastopol: Veber, 2013. - P. 318-319 [in Russian].

[9] Narytnik T.N., Ilchenko M. Ye., Radzikhovsky V. N. Radio channel research for terahertz band telecommunication systems of next-generation //Proceedings of $10^{\text {th }} \mathrm{In}-$ ternational Conference "Problems in telecommunications", Kyiv, Ukraine, April 22-25, 2014 - Kyiv: NTUU KPI, 2014 - P.137 - 140. [in Ukrainian].

[10] Narytnik T.N. Possibilities of Using THz-Band Radio Communication Channels for Super High-Rate Backhaul // Telecommunications and Radio Engineering. 2014. - №73 (15). - P.1361-1371.

Received in final form on September 16, 2016 
Авдєєнко Г.Л., Срмаков А.В., Наритник Т.М.

Дослідження передачі телевізійних сигналів стандарту DVB-C по приймально-передавальному тракту терагерцового діапазону

Проблематика. На даний час для побудови телекомунікаційної інфраструктури провідних країн світу широкого застосування отримали цифрові радіорелейні лінї зв'язку (ЦРРЛЗ), що переважно працюють в діапазоні сантиметрових хвиль та нижній частині діапазону міліметрових хвиль $(3,4-40,5$ ГГц). Однак через нестачу радіочастотного ресурсу та необхідність передачі високошвидкісних потоків інформації останнім часом при розгортанні нових ЦРРЛЗ спостерігається тенденція до подальшого переходу та освоєння верхньої ділянки діапазону міліметрових хвиль, радіорелейне обладнання якого широко представлено провідними виробниками на телекомунікаційному ринку. Перспективним для побудови майбутніх ЦРРЛЗ є також й терагерцовий діапазон частот $100-3000$ ГГц, який має дуже велику інформаційну ємність, але який поки що не використовуться через складність побудови радіотракту радіорелейного обладнання. Науково-дослідний інститут телекомунікацій та Інститут електроніки та зв'язку Української Академії наук розробили макет прийомопередавача діапазону 130-132 ГГц, внаслідок чого актуальною стала задача тестування якості роботи його окремих блоків шляхом дослідження зміни параметрів сигналів, що передаються через нього.

Мета досліджень. Дослідження зміни параметрів багатоканального сигналу цифрового телебачення стандарту DVB-C при його передачі через макет приймально-передавального тракту діапазону 130 ГГц. Стандарт DVB-C для проведення досліджень було обрано через можливість формування сигналів з різною позиційністю модуляції (від QАМ-64 до QAM-256), що дозволило дослідити вплив параметрів окремих вузлів макету на параметри сигналів, що передавалися через нього.

Методика реалізації. Для дослідження було зібрано експериментальну установку, до складу якої увійшли прийомопередавач, підсистема формування телевізійних сигналів стандарту DVB-C, підсистема вимірювання параметрів сигналів стандарту DVB-C. Дослідження проводилось поетапно: було використано одноканальний, двохканальний та трьохканальний сигнали DVB-C.

Результати досліджень. Результати дослідження показали, що використання нижньої частини терагерцового діапазону частот (130 ГГц) зі смугою 24 МГц дозволяє передати через прийомопередавач, що має спільний гетеродин для передавального та приймального тракту, три канали телевізійного мовлення стандарту DVB-C iз загальною швидкістю транспортного потоку на рівні 125 МБіт/с з високою суб’єктивною якістю відтворення всіх ТВ програм.

Висновки. Проведене дослідження вказує на високу якість передачі сигналів цифрового телебачення стандарту DVB-C прийопомередавачем терагерцового діапазону, оскільки нелінійні спотворення тракту не були помічені а фазові шуми гетеродину не викликали значного розсіювання символів на сигнальному сузір'ї. Подальшим кроком буде дослідження якості передачі сигналів стандарту DVB-C для випадку радіолінії та окремих гетеродинів в передавальному та приймальному трактах. Прийомопередавач в подальшому може бути використаний для побудови ЦРРЛЗ терагерцового діапазону для передачі та прийому високошвидкісних сигналів цифрового телебачення, Інтернету тощо.

Ключові слова: Терагерцовий діапазон; прийомопередавач; приймально-передавальний тракт; багатоканальний сигнал цифрового телебачення; стандарт DVB-C.

\section{Авдеенко Г.Л., Ермаков А.В., Нарытник Т.Н. \\ Исследование передачи телевизионных сигналов стандарта DVB-C по приемо-передающему тракту терагерцового диапазона}

Проблематика. В настоящее время для построения телекоммуникационной инфраструктуры ведущих стран мира широкое применение получили цифровые радиорелейные линии связи, которые преимущественно работают в диапазоне сантиметровых волн и нижней части диапазона миллиметровых волн $(3,4-40,5$ ГГц). Однако, из-за нехватки радиочастотного ресурса и необходимости передачи высокоскоростных потоков информации в последнее время при развертывании новых ЦРРЛЗ наблюдается тенденция к дальнейшему переходу и освоению верхнего участка диапазона миллиметровых волн, радиорелейное оборудование которого широко представлено ведущими производителями на телекоммуникационном рынке. Перспективным для построения будущих ЦРРЛЗ является также и терагерцовый диапазон частот 100 - 3000 ГГц, который имеет очень большую информационную ёмкость, но который пока ещё не используется из-за сложности построения радиотракта радиорелейного оборудования. Научно-исследовательский институт телекоммуникаций и Институт електроники и связи Украинской академии наук разработали макет приемопередатчика диапазона 130 - 132 ГГц, вследствие чего актуальной стала задача тестирования качества работы его отдельных блоков путем изменения параметров сигналов, которые передаются через него.

Цель исследований. Исследование изменения параметров многоканального сигнала цифрового телевидения стандарта DVB-C при его передаче через макет приемо-передающего тракта диапазона 130 ГГц. Стандарт DVB-C для проведения исследований был выбран из-за возможности формирования сигналов с разной позиционностью модуляции (от QAM-64 до QAM-256), что позволило исследовать влияние параметров отдельных узлов макета на параметры сигналов, которые через него передавались. 
Методика реализации. Для исследования была собрана экспериментальная установка, в состав которой вошли приемопередатчик, подсистема формирования телевизионных сигналов стандарта DVB-C, подсистема измерения параметров сигналов стандарта DVB-C. Исследование проводилось поэтапно: были использованы одноканальный, двухканальный и трехканальный сигналы DVB-C.

Результаты исследований. Результаты исследования показали, что использование нижнего участка терагерцового диапазона частот (130 ГГц) с полосой частот 24 МГц позволяет передать через приемопередатчик, имеющий общий гетеродин для передающего и приемного трактов, три канала телевизионного вещания стандарту DVB-C с общей скоростью транспортного потока на уровне 125 Мбит/с с высоким субъективным качеством воспроизведения всех ТВ программ.

Выводы. Проведенное исследование показывает на высокое качество передачи сигналов цифрового телевидения стандарта DVB-C приемопередатчиком терагерцового диапазона, так как нелинейные искажения тракта замечены не были, а фазовые шумы гетеродина не вызвали значительного разсеяния символов на сигнальном созвездии. Дальнейшим шагом будет исследование качества передачи сигналов стандарта DVB-C для случая радиолинии и отдельных гетеродинов в передающем и приемном трактах. Приемопередатчик в дальнейшем может быть использован для построения ЦРРЛЗ терагерцового диапазона для передачи и приема высокоскоростных сигналов цифрового телевидения, Интернета и.т.п.

Ключевые слова: терагерцовый диапазон; приемопередатчик; приемо-передавающий тракт; многоканальный сигнал цифрового телевидения; стандарт DVB-C. 